\title{
O infanticídio como expressão da violência e negação do mito do amor materno
}

Resumo: Discutimos neste artigo o crime de infanticídio no Brasil, buscando compreender as raízes históricas da maternidade e da violência, relacionando-as com a categoria classe social, pois os dados apontam para o fato de que as mulheres envolvidas com este tipo de crime pertencem em geral às camadas populares. Nessa perspectiva, apresentaremos dados de uma pesquisa sobre o crime de infanticídio no Brasil, realizada na Universidade Estadual de Goiás em 2012, intitulada "O infanticídio na sociedade brasileira: um estudo das dimensões social, histórica e cultural".

Palavras-chave: infanticídio; maternidade; mulher; violência

\section{Introdução}

A sociedade moderna é um deserto, habitado por bestas selvagens. Cada indivíduo está isolado dos demais, é um entre milhões, numa espécie de solidão em massa. Karl Marx

Este artigo trabalha com dados de uma pesquisa aprovada pela Pró-Reitoria de Pesquisa e Pós-Graduação da Universidade Estadual de Goiás, realizada em 2012, cujo tema foi "O infanticídio na sociedade brasileira: um estudo das dimensões social, histórica e cultural". O corpus da pesquisa foi constituído por vinte e um processos de mulheres acusadas do crime de infanticídio em diferentes regiões do país: um em Minas Gerais; dois no Distrito Federal; três no Paraná; sete no Rio Grande do Sul; cinco em São Paulo e três em Goiás. São processos em nível de recurso em segundo grau de jurisdição, ou seja, Acórdãos relacionados a processos criminais concernentes à prática de infanticídio.

Propusemos, inicialmente, pesquisar o período entre os anos de 2008 e 2010; mas, o volume reduzido de casos de infanticídio nos fez rever tal critério. Além disso, havia apenas dois processos disponíveis no site Jusbrasil que foram julgados antes de 2008, sendo um

\section{(c) (7)}

Esta obra está sob licença Creative Commons. 
de 2005 e outro de 2007. Resolvemos, então, incluí-los juntamente com outros dois que haviam sido julgados depois de 2010, sendo um de 2011 e outro de 2012.

No entanto, justificamos o recorte de apenas dois casos concretos para a presente análise devido ao espaço limitado previsto para este artigo. A escolha dos processos aqui tratados está relacionada com a representatividade dos casos tipificados nos dois Acórdãos' de Apelação Criminal: um do Tribunal de Justiça do Rio Grande do Sul e outro do Tribunal de Justiça de Minas Gerais. Ambos tratam de mulheres acusadas de infanticídio cujas histórias constam de elementos que tornam possível um aprofundamento em uma discussão acerca das condições sociais, econômicas e culturais que, em geral, tais casos apresentam.

\section{A mulher brasileira e a emergência da modernidade}

A partir do final do século XIX, com a industrialização no Brasil, as mulheres das camadas populares passaram por profundas mudanças em sua situação conjugal e condição de trabalho. Idealisticamente, a burguesia em ascensão percebia as mulheres como recatadas, voltadas para a vida do lar, onde deveriam se ocupar dos afazeres domésticos e dos cuidados com os filhos, enquanto os homens deveriam assegurar o sustento da família. A pesquisa de Rachel SOIHET (1997, p. 367) nos mostra que essas mulheres possuíam uma rotina dura de trabalho, uma vez que a maioria não era formalmente casada e, além disso, as dificuldades e contradições de suas existências as levavam a se envolverem em brigas e outras transgressões, fugindo, dessa forma, aos estereótipos atribuídos ao sexo feminino, construídos desde os tempos coloniais para manter a divisão de classes.

Entretanto, a presença marcante dessas mulheres na sociedade brasileira não se mostrou suficiente para contrapor a construção de ideias biologicistas no tocante à distinção dos papéis sociais, calcada na diferença e peculiaridade sexuais, concebida e aceita como fenômeno estabelecido pela própria natureza humana. Para Rosemary de Oliveira ALMEIDA (2001, p. 87), o domínio masculino foi imposto como ordem objetiva e simbólica por meio da socialização dos papéis sexuais, cabendo à mulher permanecer no espaço doméstico e ao homem o desbravamento do lugar público. Essa naturalização da condição feminina ocorreu principalmente sob a justificativa da divisão social do trabalho.

Essa tentativa de adestramento da mulher voltada para a submissão e os afazeres domésticos remonta ao período colonial. Nessa perspectiva, a historiadora Mary DEL PRIORE (1993) argumenta que, além da efetiva participação da escola e da igreja, a domesticação da mulher contou também com um importante instrumento de controle - o discurso médico - que, ao assegurar ser a procriação a principal função do corpo feminino, servia para confirmar o discurso religioso sobre a função da sexualidade voltada exclusivamente para a reprodução humana.

Por outro lado, no Brasil escravocrata, tal controle estava reservado à mulher branca, a qual representava os requisitos fundamentais para submeter-se, sem contestação, ao poder do patriarca. Para a pesquisadora feminista Heleieth SAFFIOTI (1979), apenas excepcionalmente a colonização se fazia por meio da vinda de grupos familiais constituídos; tratava-se, em geral, de indivíduos isolados que chegavam ao Brasil deixando as famílias à espera da fortuna a ser conquistada na nova terra. Porém, as facilidades sexuais proporcionadas pela existência de mulheres submissas e de condição social inferior assumiram importante papel no prolongamento da espera, por parte da família do colono, de seu regresso à Europa.

Com exceção da família patriarcal da camada dominante, tudo nesse período era permitido. A própria organização familial do branco supunha a não organização de uma

${ }^{1}$ Refere-se a decisões proferidas pelos tribunais judiciários em segundo grau de jurisdição. 
família escrava. Dada à socialização da mulher branca para o desempenho dos papéis de dona de casa e mãe de família legalmente constituída, necessário se fazia a existência de uma classe de mulheres com as quais os jovens brancos pudessem praticar "as artes do amor" antes e depois do casamento. Assim, a escravidão satisfazia não apenas as exigências do sistema produtivo, mas ainda aquelas impostas pela forma de colonização adotada e as de uma família branca na qual à mulher cabia, essencialmente, o papel de mãe da prole legítima.

O modelo imposto pela estrutura internacional de poder na formação econômicosocial capitalista no Brasil se constituiu de forma dependente. A realização dos objetivos deste sistema nos níveis alcançados pelas sociedades de consumo de massas constitui o ponto inicial para compreendermos os papéis sociais que homens e mulheres historicamente desempenharam na sociedade brasileira desde seus primórdios. A fim de exemplificar a primazia do caráter econômico e de classe, ao invés de racial que marcava as relações durante o período da colonização, Saffioti (1979) afirma que, apesar da rígida assimetria que caracterizava as relações senhor-escravo, o fundamento pecuniário da escravidão e a miscigenação constituíam-se em fatores de perturbações daquelas relações.

A maneira meramente formal mediante a qual a camada dominante resguardava seu domínio, impedindo casamentos inter-raciais, mas não impedindo a miscigenação, deixava transparecer que o econômico - e não o racial - era o verdadeiro fundamento da divisão da população em castas. A inexistência de repugnância mútua entre as camadas constituintes da sociedade escravocrata configuraria uma especial estratificação em castas nas quais a raça desempenharia meramente a função de símbolo da condição econômica dos indivíduos. Logo, em relação aos papéis femininos, essa inconsistência cultural do sistema de castas no Brasil teve consequências de ordem diversas.

A mais importante inconsistência, segundo Saffioti (1979), aparece quando examinamos os papéis cujo desempenho estava sujeita a mulher negra, já que cabia à escrava, além de uma função no sistema produtivo de bens e serviços, um papel sexual, via de uma maior reificação e, simultaneamente, linha condutora do desvendamento do verdadeiro fundamento da sociedade de castas. Assim, se por um lado a função da negra escrava, enquanto simples instrumento de prazer sexual de seu senhor, não indica que nesta relação as partes envolvidas tenham superado o nível primário e puramente animal do contato sexual, por outro lado, o produto desta relação assume, na pessoa do mestiço, a forma de um foco dinâmico de tensões sociais e culturais.

Deste modo, a exploração econômica da escrava, consideravelmente mais elevada que a do escravo - por ser a negra explorada também por meio do seu sexo, além, é claro de ser utilizada como reprodutora de força de trabalho -, se constituía no instrumento inconsciente que, paulatinamente, minava a ordem estabelecida, quer na sua dimensão econômica, quer na sua dimensão familiar. Por consequência, ao se posicionar como objeto de desejo do homem branco, a mulher negra, por um lado, levava o senhor a adotar comportamentos antieconômicos, tais como a venda e a tortura de negros com os quais aquele competia no terreno sexual; por outro lado, as relações sexuais entre senhores e escravas desencadeavam, por mais primárias e bárbaras que fossem, processos de interação social incongruentes com as expectativas de comportamento que presidiam à estratificação em castas. Por isso, não apenas homens brancos e negros se tornavam concorrentes na disputa das negras, mas também mulheres brancas e negras disputavam as atenções do homem branco. Evidentemente a rivalidade entre brancas e negras não se configurava como uma típica competição, posto que, pelo sistema de castas, os fins a que se destinavam umas e outras eram completamente diferentes. 
O marco dessa diferença é bastante evidente se observarmos o papel da mulher branca na casa grande. Ela desempenhava, na maioria das vezes, uma importante função no comando e supervisão das atividades realizadas no lar. Ainda de acordo com Saffioti (1979), a senhora não dirigia apenas o trabalho da escravaria na cozinha, mas também na fiação, na tecelagem, na costura, supervisionava a confecção de rendas e o bordado, a feitura da comida dos escravos, os serviços do pomar e do jardim, o cuidado das crianças e dos animais domésticos, providenciava tudo para o sucesso dos encontros comemorativos que reuniam toda a parentela. Tudo isso compunha o domínio próprio, o universo social e cultural da mulher que dificilmente permitiria às mães a indolência e a passividade atribuída a elas. Em quase todo o país a vida era dura para a maioria, e da mulher esperava-se que desempenhasse seu papel de forma impecável. Desse modo, não são raros os casos em que as viúvas tomaram a direção dos negócios da família com energia e sucesso, revelando-se líderes competentes, mas também casos em que a esposa de um homem incapaz ou incapacitado tomou seu lugar na chefia da família.

Essa breve contextualização da mulher no Brasil Colônia tem apenas o intuito de contribuir para desmistificar a crença de que as mulheres são e foram igualmente submetidas a um mesmo processo de exploração e dominação. A condição da mulher escrava, assim como da mulher livre e pobre, era completamente diferente da condição assumida pela senhora "esposa" do grande senhor escravocrata.

Muitos são ainda os mitos que sobrevivem - mesmo no âmbito da academia - sobre a questão da mulher. Ultimamente tornou-se "moda" entre professores e outros profissionais da educação básica, aflitos com a crescente onda de violência e indisciplina nas escolas, buscar explicações para o fenômeno vinculando-o à inserção da mulher no mercado de trabalho. Argumentam, nesse sentido, que esse foi o fato desencadeador para quase todos os problemas que as famílias enfrentam, pois haveria, segundo tais análises, uma "desestruturação familiar" que pode provocar comportamentos violentos na criança e, consequentemente, um baixo rendimento na escola.

Para os que defendem essa ideia teria existido no passado uma mulher exclusivamente dedicada aos afazeres de mãe e dona de casa em contraposição à mulher que agora trabalha fora do lar, provocando com isso uma crise na família, na escola e na sociedade. Todavia, a mulher, especialmente a mulher pobre, seja nos tempos da colonização, do império ou da república, sempre esteve submetida ao mundo do trabalho e a condição desse trabalho nunca foi e não é igual para todas as mulheres.

Logo, para melhor compreendermos a fonte original de argumentos sobre a suposta desestruturação familiar, precisamos nos lembrar das especificidades do movimento desencadeado pelos médicos higienistas no século XIX, quando procuravam impedir o avanço do processo de libertação da mulher brasileira. Os médicos higienistas estavam preocupados em disciplinar e construir o modelo da mãe de elite que deveria, no entendimento destes profissionais, voltar-se exclusivamente para as tarefas do lar, daí toda a preocupação em convencer essas mulheres da importância da amamentação. Para Jurandir Freire COSTA (1999), a construção do modelo de mãe amorosa que alimenta seu bebê tinha outros objetivos, pois além de proteger a vida das crianças, regulava a vida da mulher. $O$ autor ainda enfatiza que a segregação doméstica da mulher, por meio da alimentação, estava ligada à concorrência com o homem, já que a emancipação do patriarcado colonial e a urbanização haviam gerado uma entusiástica onda de independência feminina.

Os médicos higienistas elaboraram então um conjunto de normas e valores onde implicitamente a independência da mulher não poderia extrapolar as fronteiras da casa e do consumo de bens e ideias que reforçassem a imagem da mulher-mãe. Por isso sua 
participação na vida intelectual do país era inadmissível. A mulher intelectual representava um mau exemplo às outras mulheres, podendo levá-las a acreditar que poderiam subsistir de forma independente dos pais ou maridos. Logo, a emancipação da mulher, que certamente envolvia sua profissionalização, comprometia o pacto machista estabelecido entre o homem e os higienistas.

Foi a partir do imaginário sobre a existência de uma natureza feminina, porém, que se construiu o mito do amor materno. Concebido como um instinto natural de todas as mulheres, este argumento é largamente utilizado ainda hoje pelos operadores do direito quando estes se deparam com o crime de infanticídio. Contrapondo-se a este argumento, Elisabeth BADINTER (1985, p. 68) nos mostra dados sobre a maternidade na França dos séculos XVI e XVII que comprovam a indiferença da mulher diante da maternidade. Segundo o relatório de polícia de 1780 citado pela autora:

Das 21 mil crianças que nascem anualmente em Paris, apenas mil são amamentadas pela mãe. Outras mil, privilegiadas, são amamentadas por amas-de-leite residentes. Todas as outras deixam o seio materno para serem criadas no domicílio mais ou menos distante de uma ama mercenária. São numerosas as crianças que morrerão sem ter jamais conhecido o olhar da mãe [...].

A partir destes e de outros dados, Badinter (1985) apresenta uma realidade onde o interesse das mães pelos filhos, até o século XVIII, era bastante reduzido, o que a faz considerar que o amor materno é apenas um sentimento humano. E como todo sentimento, é incerto, frágil e imperfeito. Ao observar a evolução das atitudes maternas, constata-se que o interesse e a dedicação à criança se manifestam ou não se manifestam, isto é, o afeto existe ou não existe. Percebe-se, assim, que as diferentes maneiras de expressar o amor materno vão do mais ao mais ou menos, passando pelo nada ou o quase nada.

Acreditamos que essas diferentes maneiras de desenvolver e expressar o amor materno decorrem quase sempre a partir do apoio e afeto que essa mulher possui ou não em sua rede de relações familiares ou de amizade durante a gravidez e depois dela. No entanto, como veremos no tópico que segue, esse aspecto, ou mesmo a não autonomia profissional e econômica das mulheres acusadas do crime de infanticídio, não consta dos debates realizados pelos operadores do direito. Ao invés disso, tais profissionais associam o infanticídio à noção de loucura puerperal, uma categoria biologista que tem sua origem na medicina.

\section{Infanticídio: casos concretos}

Dentre os chamados "crimes femininos", optamos pelo infanticídio, considerando sua pequena incidência e o fato de ser praticado exclusivamente pela mulher-mãe. Além disso, são poucos os registros organizados que nos permitem reconstruir a atuação das mulheres envolvidas em atos de violências, uma vez que predomina em nossa sociedade o paradigma da ciência positivista que dá primazia aos aspectos biológicos e estabelece para a mulher características relacionadas com a fragilidade, o recato, o predomínio das faculdades afetivas sobre as intelectuais e a subordinação da sexualidade à vocação maternal. Nesse sentido, a documentação policial e judiciária revela-se como material privilegiado que nos possibilita perceber preconceitos, estereótipos, violências e motivações que, produzidas em nome da ordem, constituem-se como estratégia política para perpetuar a opressão e a violência.

Nos processos que foram consultados, percebe-se que as mulheres, mesmo antes de praticarem o crime de infanticídio, encontravam-se cotidianamente isoladas, submetidas a trabalhos precarizados e a relações familiares repressivas e autoritárias. Nesse sentido, é 
emblemático o caso de Susana de Oliveira, ${ }^{2}$ que teve seu julgamento realizado pelo Tribunal de Justiça do Rio Grande do Sul em 05 de maio de 2010.

De início, Susana foi denunciada pelo crime de homicídio, consoante art. $121, \S 2^{\circ}$, incisos I e III c/c art. 121, § $4^{\circ}$, in fine, e art. 61, inciso II, alínea e (descendente), todos do Código Penal. No entanto, a magistrada responsável pelo caso considerou que a existência do fato (materialidade) não foi comprovada e, por isso, impronunciou a ré em relação às acusações feitas pelo Ministério Público que, então, recorreu dessa decisão. O novo julgamento concedeu parcial provimento ao apelo do Ministério Público e julgou Susana culpada de infanticídio (art. 123 do Código Penal).

Apesar da linguagem técnica e burocrática do Relatório elaborado pelo Desembargador Marcel Hoppe sobre o crime praticado por Susana, pode-se extrair algumas informações que retratam a dramaticidade dessa mulher. No processo, o delegado responsável pela denúncia afirma que Susana escondeu a gestação das pessoas do seu círculo familiar e quando estava no período previsto para dar a luz à criança trancafiou-se no banheiro de sua residência, local onde deu início ao trabalho de parto. Em seguida, após a criança ter nascido com vida, segundo a denúncia, Susana, de forma não precisamente apurada, asfixiou o bebê que, depois, foi encontrado, já sem vida, no interior de um tanque de acrílico coberto por panos.

Durante o interrogatório, Susana afirmou que escondeu sua gravidez porque temia ser repudiada por seus pais, que são muito rígidos. Narra ainda que sua situação se tornou ainda mais delicada porque o pai da criança sumiu logo após saber da notícia de sua gravidez. $\mathrm{O}$ isolamento e a falta de apoio são visíveis. Susana conta que não fez nenhum exame pré-natal e, mesmo no dia em que entrou em trabalho de parto, estava em seu emprego (empregada doméstica) e sua patroa apenas desconfiou, mas como ela negou que estivesse grávida, a patroa nada fez. Para aliviar as fortes dores do parto, Susana tomou vários banhos, sendo que no último começou a ficar tonta e quando já não estava mais suportando a dor, sentiu que algo caiu e, em seguida, desmaiou.

Quando acordou, Susana estava em uma poça de sangue e não sabia o que fazer. Relata que olhou para o chão e a criança estava lá, pegou no colo, mas continuou sem saber o que fazer. A criança, segundo ela, não se mexia e continuava com os olhos fechados. Então, amedrontada e insegura, pensou que naquelas condições em que ocorreu o parto a criança já devia estar morta. A única alternativa que conseguiu pensar naquele momento foi deixar a criança ali mesmo, ao lado, dentro de um tanque vazio, sem água em seu interior.

Logo depois, o bebê foi encontrado sem vida e o segredo guardado durante nove meses foi descoberto. Percebendo então seu estado lastimável, a patroa levou Susana ao hospital, quando ela então confessou que se sentia rejeitada e discriminada pelos pais adotivos, pois sempre percebeu que os irmãos brancos, isto é, os filhos biológicos, eram os preferidos pelos pais.

A dramática situação de Susana em nada sensibilizou os operadores do direito. Neste caso específico, o Ministério Público reiteradamente procurou mostrar a crueldade da mulher, buscando acusá-la de homicídio e não de infanticídio. Todavia, o Desembargador relator do processo argumentou que existiam indícios de autoria do crime, porém, não poderia classificá-lo como homicídio e sim infanticídio, previsto no art. 123 do Código Penal, que ocorre quando a mulher mata o próprio filho durante o parto ou logo após, sob a influência do estado puerperal. ${ }^{3}$ Depois dessa classificação do crime, o relator

\footnotetext{
${ }^{2}$ Embora os Acórdãos estejam disponíveis no site Jusbrasil, optamos por utilizar nomes fictícios para garantir a privacidade das mulheres acusadas de infanticídio.

3 "Art. 123 - Matar, sob a influência do estado puerperal, o próprio filho, durante o parto ou logo após: Pena - detenção, de dois a seis anos".
}

6 Revista Estudos Feministas, Florianópolis, 26(1): e41476 
do processo procurou brevemente esclarecer o significado do estado puerperal, deixando claro que são perturbações de ordem física e psicológica que acometem as mulheres e são decorrentes do parto. Acrescenta ainda que tais transtornos produzem sentimentos de angústia, ódio, desespero, levando a mãe a eliminar o próprio filho.

O que se destaca nesse documento é o caráter abstrato do "estado puerperal". É como se qualquer mulher em qualquer situação pudesse, logo após o parto, ser acometida por ele. O discurso do magistrado sobre os sentimentos de angústia, ódio e desespero das mães em estado puerperal reforça a ideia da determinação biológica. Em nenhum momento se faz menção ao fato de que o desespero, a angústia, o medo das mulheres foram forjados antes do parto, provavelmente durante toda a gravidez e até mesmo antes dela. São sentimentos que têm origem em relações familiares conflituosas, violentas e condições de vida miseráveis. Nada disso faz parte dos argumentos tecidos pelo poder judiciário. Justiça e medicina se uniram para oferecer explicações neutras para o infanticídio, sem comprometer a legitimidade das leis e, principalmente, sem formular nenhuma menção ou crítica à sociedade capitalista, cuja violência the é intrínseca.

Outro processo, contra Mariana Alves, de Belo Horizonte, Minas Gerais, diferente da maioria, apresenta alguns detalhes que nos permitem analisar a atitude da mãe, as concepções da médica responsável pelo laudo da acusada e também os argumentos produzidos pelos operadores do direito. Além disso, a singularidade deste caso diz respeito à forma utilizada pela mãe para matar a criança.

De acordo com o documento, Mariana deu à luz em 07 de setembro e logo após o parto tentou sufocar a criança, colocando-a depois no interior de um guarda-roupa, deixando-a neste local até o dia 15 de setembro. A narrativa de Mariana foi reproduzida no processo da seguinte forma:

Na noite de 07 de setembro, ao sair do banheiro em direção a seu quarto, onde também dormiam seus filhos de 3 e dois anos de idade, sentiu uma dor mais forte, segurou na janela e o bebê caiu de seu interior [...] que em seguida pegou um cobertor, embrulhou a criança e colocou-a em cima da cama; que deitou-se e dormiu; que por volta de 0:00h acordou com a criança chorando; que colocou a mão sobre a boca da mesma, para que parasse de chorar; que tornou a dormir e no dia seguinte, o irmão de Mariana bateu na sua porta [...] que balançou a criança mas a mesma não mexeu; que quando seus filhos acordaram levou-os para fora do quarto e voltou para limpá-lo; que retirou a bolsa e limpou o sangue; que a criança não chorou mais e permaneceu enrolada em cima da cama até sexta-feira, dia em que a colocou dentro do armário; que na quarta-feira da semana seguinte, retirou a criança de dentro do guarda-roupa, onde já estava enrolada no cobertor e no lençol, levou-a até o fundo da casa, colocoua no chão e cobriu com umas folhas secas de bananeira; que em seguida colocou fogo nas folhas (fls. 83/84).

O relator do Acórdão destaca o ato brutal cometido pela mãe que desde o início confessou o crime com riqueza de detalhes. Rebate, assim, o argumento da própria Mariana quando esta afirma que supunha o bebê morto quando lhe ateou fogo. Para o relator, isso não retira o dolo antecedente, pois, desde que seu filho nasceu, ela pretendia, ao que tudo indica, matá-lo asfixiado, justamente para esconder de vizinhos e familiares a gravidez indesejada. Resta, então, segundo o relator, averiguar se realmente a conduta perpetrada pela ré se amolda ao tipo penal do artigo 123 do Código Penal (2003 [1940]): "matar, sob influência do estado puerperal, o próprio filho, durante o parto ou logo após".

Alerta o relator para a irrelevância da alegada vergonha decorrente de uma gravidez indesejada e fora dos limites matrimoniais, ao mesmo tempo em que ressalta a importância do critério fisiopsíquico adotado pelo Código Penal (2003 [1940]) que se baseia em um 
desequilíbrio físico e hormonal sofrido pela mulher durante a gravidez e que pode se agravar no momento do parto. Todavia, o Magistrado lembra ainda que não basta à tipificação do delito o simples fato de a mulher encontrar-se no estado puerperal; imprescindível que aludida condição tenha influenciado diretamente a mãe ao matar seu filho, prejudicando ou diminuindo sua capacidade de agir livremente. Por isso, afirma no relatório do Acórdão: "não vejo como manter a pronúncia da ré por homicídio qualificado, eis que presentes, na espécie, as elementares do tipo penal infanticídio". Explica ainda o Magistrado que, embora já tenham sido realizados exames médicos, a Magistrada responsável pelo processo em primeiro grau entendeu que o laudo produzido não era concludente quanto à gravidade do estado puerperal, razão pela qual determinou de ofício a realização de nova perícia, nomeando, na oportunidade, a Dra. Maria Angélica Galvão Longo e estabelecido os quesitos a serem respondidos. Entretanto, a médica, alegando razões de foro íntimo, solicitou a nomeação de outro perito, o que foi realizado.

Contudo, a Dra. Maria Angélica acabou sendo ouvida como testemunha especializada e seu depoimento é elucidativo pois, diferente dos demais, ela não "naturaliza" a condição da mulher em estado puerperal:

[...] os casos de depressão pós-parto são mais frequentes na rede pública, onde normalmente se atendem pessoas carentes. Conclui-se, outrossim, que a própria condição sócio-econômica da parturiente pode contribuir sobremaneira para desencadear as alterações psíquicas do estado puerperal (Processo n. 1.0702.04.1702516/001 (1), p. 118)

A partir do depoimento da Dra. Maria Angélica, o próprio Magistrado, relator do processo, conclui que a condição socioeconômica da parturiente pode contribuir para desencadear as alterações psíquicas do estado puerperal. Essa observação é incomum nos processos analisados, pois, via de regra, os operadores do direito não fazem referências às condições sociais das mulheres acusadas. Essa exceção nos mostra a importância do discurso científico, visto que o Magistrado assim justifica sua conclusão: "Ora, a partir do momento em que os elementos coligidos aos autos, notadamente a perícia médica, evidenciam que a acusada agiu sob a influência do estado puerperal, incumbia à acusação desconstituir referida conclusão [...]" (Processo n. 1.0702.04.170251-6/001 (1), p. 118).

O Magistrado ressalta o valor da perícia médica que fez referência à relevância dos aspectos social e econômico das mulheres que cometem o crime de infanticídio. Todavia, a Dra. Maria Angélica atuou no processo como testemunha especializada, pois alegando razões de "foro íntimo" ela havia solicitado a nomeação de um substituto. Fica claro, então, que ela não forneceu um laudo, mas somente se dispôs a narrar sua experiência de trabalho no atendimento a mulheres pobres da rede pública de saúde.

De qualquer maneira, consideramos que o depoimento da Dra. Maria Angélica foi importante, pois o crime de Mariana foi desclassificado como homicídio qualificado e, por conseguinte, classificado como infanticídio pelo Tribunal de Justiça de Minas Gerais (2009). É salutar atentarmos para a mudança cultural que subjaz a narrativa do Juiz que julgou o processo de Mariana. Ao chamar atenção para a "irrelevância da alegada vergonha decorrente de uma gravidez indesejada e fora dos limites matrimoniais" (p. 119), o Magistrado se contrapõe diretamente ao discurso padrão da escola jurídica positivista, cujos pressupostos, até a primeira metade do século XX, estavam em sintonia com 0 posicionamento de advogados, juízes e promotores.

Fabíola ROHDEN (2003), ao acessar inquéritos e processos do referido período, confirma a influência do positivismo e, a título de exemplo, afirma que, em um caso de defloramento ou estupro, a acusação ao autor do atentado só fazia sentido, provocando um processo criminal, 
se ficasse provado que se tratava de uma moça "honesta". Segundo a autora, essa concepção levava em conta a conduta do réu não apenas no momento do crime, mas dentro do quadro de sua personalidade, determinando o quão perigoso o indivíduo era para a sociedade ou a gravidade das normas sociais que foram rompidas. Nesse sentido, o comportamento das mulheres ofendidas adquiria maior importância do que o ato dos acusados. Os juristas avaliavam se elas mereceram ou não o crime cometido e se teriam ou não proteção.

Nesse contexto, as testemunhas eram fundamentais para que se compusesse o quadro de informações sobre a envolvida (incluindo lazer, moradia, namoro, trabalho, estrutura familiar, amizades etc.) que servia aos advogados e promotores na definição do caso. $O$ importante, porém, é que essas informações eram avaliadas de acordo com os padrões sociais concebidos por estes últimos e não aqueles vigentes nas camadas às quais pertenciam os envolvidos.

A pesquisa de Rohden (2003) constitui-se em uma importante fonte de conhecimento sobre a centralidade dos valores patriarcais conservadores que embasavam a visão dos operadores do direito da primeira metade do século XX. Em consulta à Revista Forense, a pesquisadora identificou um artigo publicado em 1942, de autoria do promotor público de Porto Alegre, Henrique Fonseca de Araújo, o qual afirmava que a única razão para que se dê um tratamento especial no caso do infanticídio é a defesa da honra da mulher. Para o promotor, não se pode colocar em pé de igualdade a mãe que mata o filho, fruto de uma união legal, por puro egoísmo ou para se furtar dos encargos da maternidade, e aquela que mata para ocultar a sua desonra, decorrente de um filho concebido fora do casamento.

Para este promotor existiriam dois motivos essenciais para o crime de infanticídio: o egoísmo da mulher e a consequente tentativa de se livrar dos trabalhos decorrentes da maternidade ou a necessidade de se livrar da desonra. O objetivo de seu artigo era principalmente criticar o novo código penal de 1940 e, ao mesmo tempo, defender a premissa básica do antigo código, de 1890, cujo princípio, segundo ele, era político e não ascético, pois levava em consideração o fato de que a mulher, autora de infanticídio, agiu pensando na sua honra, ou melhor, como uma delinquente menos perigosa, diferente do homicida vulgar. De acordo com essa concepção, a mulher que comete tal crime, em parte o faz movida por um sentimento de respeito aos postulados morais que regem a sociedade na qual vive. Corroborando a tese da defesa da honra, o estudo de Gláucio Vasconcelos RIBEIRO (2004) sobre a evolução do infanticídio na legislação brasileira também nos mostra que tanto o código criminal de 1830 como o código penal de 1890 tinham como critério definidor do infanticídio a honoris causa, ${ }^{4}$ bem como admitiam a prática do infanticídio por terceira pessoa. Inferimos, portanto, que o infanticídio se configura em consonância com as condições sócio-históricas construídas socialmente.

A relação entre crime e loucura encontra-se explícita nos códigos penais de 1890 e de 1940. No primeiro, em seu artigo 27, parágrafo quarto, definia que não era criminoso aquele que se achasse em estado de completa privação de sentidos e de inteligência no momento em que cometeu o crime. Ora, a chamada loucura puerperal era identificada justamente como uma das perturbações mentais capazes de interromper temporariamente a razão e a consciência das mulheres. Já no código penal de 1940 declara-se de forma clara o infanticídio como crime cometido exclusivamente pela mãe, em "estado puerperal". Rompeu-se, dessa forma, com o critério do honoris causa e adotou-se o critério fisiopsíquico que leva em conta o desequilíbrio físico e hormonal sofrido pela mulher durante a gravidez e seu consequente agravamento na hora do parto. A leitura dos criminologistas sobre o crime, em geral cometido pela mulher, segundo Almeida (2001), possui fundamentação na

${ }^{4}$ Se o crime fosse praticado com a pretensão de ocultar a desonra da mãe infanticida. 
teoria de Cesare Lombroso, médico e criminalista italiano, o qual afirmava que a mulher tem tendência ao homicídio passional, movida pelo ciúme e pela vingança. Essa tendência seria manifestada principalmente na mulher prostituta, derivativo criminal das mulheres. Quanto à mulher normal, Lombroso a considerava apenas como um ser inferior, dada ao instinto e não à inteligência e, próxima dos selvagens, malvada por índole. A mulher criminosa seria ainda mais inferior, pois teria analogia com a estrutura psíquica e física do criminoso nato que se aproxima do monstro pelos traços físicos de regressão da espécie. A mulher seria, então, menos propícia ao crime, mas poderia também cometê-lo, sendo desviantes as prostitutas e as criminosas natas.

Desse modo, quase sempre fundamentados nas assertivas relatadas, os criminalistas do século XIX entendiam que as mulheres delinquiam em função dos aspectos biológicos e, quando muito, sociais, tendo em vista a vulnerabilidade por que passaram na modernidade com a sua inserção no mundo do trabalho que, por sua vez, as afastou do mundo harmonioso das relações tradicionais da família. Todavia, ainda no século XIX, Karl MARX (2006), em seus escritos "sobre o suicídio", nos alertou para este falso moralismo dos burgueses, cujas pretensões se fundamentavam na ideia de que se tratava apenas de dar aos proletários um pouco de pão e educação, como se somente os trabalhadores definhassem sob as condições sociais vigentes naquele período, ao passo que, para o restante da sociedade, o mundo tal como existia fosse o melhor dos mundos. Daqueles tempos aos dias atuais não ocorreu nenhuma mudança capaz de romper radicalmente com a opressão. Permanece, portanto, pertinente sua crítica das relações de propriedade, das relações familiares e das demais relações privadas - em uma palavra, a crítica da vida privada, a qual surge como o necessário resultado de suas experiências políticas.

As críticas e as lutas do movimento feminista também foram (e são) essenciais ao direito, principalmente no que se refere à denúncia quanto às discriminações contra as mulheres contidas tanto na legislação quanto na prática jurídica do direito criminal.

A partir do início dos anos setenta, a posição desigual da mulher no direito penal seja na condição de vítima ou de autora de delito - passou a ser objeto de crescente atenção por parte da criminologia. [...].

A questão feminina tornou-se, assim, um componente privilegiado da questão criminal. Desde então, temas como a falta de proteção das mulheres dentro do sistema do justiça penal frente à violência masculina, a baixa taxa de incriminação feminina, bem como suas formas específicas de criminalidade (aborto e infanticídio) conseguiram sair plenamente da marginalidade acadêmica (Alessandro BARATA, 1999, p. 19).

A partir das reflexões críticas suscitadas pelo feminismo, desenvolveu-se a possibilidade de minar o modelo androcêntrico de ciência, contribuindo para introduzir mudanças no campo do direito, em especial, no âmbito penal, sob a ótica de inclusão das lutas emancipatórias das mulheres, as quais buscam superar as amarras de uma cultura patriarcal e reprodutora de discriminação. Nesse sentido,

[...] o movimento feminista foi conquistando clareza teórica e força política na medida em que buscou a concretude da variável do gênero na relação com outras variáveis sociais, e em que definiu a questão feminina como a questão humana tout court (BARATA, 1999, p. 68).

As mulheres que desafiam as normas socialmente pré-estabelecidas como adequadas ao comportamento feminino, como é o caso do infanticídio, afrontam não somente a legislação penal, mas também a cultura de uma sociedade baseada na diferença de gênero a partir da construção de papéis. 


\section{Considerações provisórias}

Existe um número insignificante de ocorrências registradas nas instituições policiais concernentes ao crime de infanticídio em comparação com os dados estatísticos oficiais voltados a outras modalidades de delitos, inclusive relacionados com a mulher. No entanto, a relevância do tema centra-se na própria invisibilidade do crime de infanticídio, fato evidenciado pela ausência de uma análise que conceba a violência praticada pela mulher como um ato intrínseco à estrutura sociocultural da sociedade nas respectivas literaturas criminalista e jurídica.

Ao refletir sobre a relevância dos objetos de pesquisa, Pierre BOURDIEU (1998) ressalta que os objetos considerados em sua aparência como insignificantes são passíveis de análise, haja vista não ser a relevância social ou política de um objeto que o torna sociológico, pois "o que conta, na realidade, é a construção do objeto, e a eficácia de um método de pensar que nunca se manifesta tão bem como na sua capacidade de transformar objetos socialmente insignificantes em objetos científicos" (p. 20).

Apesar da falta de visibilidade a respeito do infanticídio, este constitui uma prática de violência antiga e corriqueira, praticada pela mulher que, devido a condições objetivas e subjetivas, não se adéqua ao ideário convencional de ser mãe. E isto demonstra que o ato de violência não está relacionado à predisposição de um determinado sexo. Desse modo, infere-se que a publicização do infanticídio depõe contra a ideologia dominante da "santa-mãe", concebida como ser doméstico imbuído de amor e ternura, dedicada à proteção dos filhos.

A partir da discussão teórica e prática a respeito do infanticídio, tem-se uma ideia da dimensão de sua complexidade, remetendo o leitor a rever criticamente padrões de valores social e cultural, difundidos pelas instituições responsáveis pela reprodução da ideologia dominante, tais como escolas, igrejas, dentre outras. Neste estudo, não tivemos a pretensão de desenhar conceitos e respostas conclusivas acerca do tema em discussão, mas convidar - leitor para refletir sobre algumas indagações: até que ponto as características da cultura brasileira, essencialmente marcada pelas relações de violência, contribuem para a continuidade do infanticídio, ou seja, para a reprodução dessa modalidade de violência? Até que ponto o estado puerperal, enquanto pressuposto do crime de infanticídio, escamoteia as relações de dominação que permeiam a sociedade capitalista? E, ainda, a prática do infanticídio desmistifica a representação da condição feminina de ser frágil e dócil?

Sem a pretensão de oferecer respostas conclusivas, defendemos que a violência deve ser concebida como um fenômeno social historicamente construído na dinâmica das relações sociais de uma dada sociedade e que abstrair a mulher do cotidiano em que ela se encontra inserida é impossível. De modo que, mesmo quando a ação violenta de uma mulher se apresenta bárbara, aparentemente incompreensível, a explicação não reside nos aspectos biológicos da constituição do ser mulher. Dentre outros motivos, a prática de violência cometida pelas mulheres consiste em um instrumento usado por elas para externar seu inconformismo frente à opressão que se expressa na negação do espaço público enquanto local destinado à ação política.

\section{Referências}

ALMEIDA, Rosemary de Oliveira. Mulheres que matam: universo imaginário do crime no feminino. Rio de Janeiro: Relume Dumará, 2001.

BADINTER, Elisabeth. Um amor conquistado: o mito do amor materno. Rio de Janeiro: Nova Fronteira, 1985. 
BARATA, Alessandro. "O paradigma do gênero: da questão criminal à questão humana". In:

CAMPOS, Carmen Hein de. Criminologia e feminismo. Porto Alegre: Sulina, 1999.

BOURDIEU, Pierre. O poder simbólico. Rio de Janeiro: Bertrand Brasil, 1998.

BRASIL. Código penal (1940). São Paulo: Revista dos Tribunais, 2003.

Código Penal Brasileiro (1890). São Paulo: Livraria Acadêmica, 1923.

COSTA, Jurandir Freire. Ordem médica e norma familiar. Rio de Janeiro: Graal, 1999.

DEL PRIORE, Mary. Ao sul do corpo: condição feminina, maternidades e mentalidades no Brasil colônia. Rio de Janeiro: José Olympio; Brasília: EDUNB, 1993.

MARX, Karl. Sobre o suicídio. São Paulo: Boitempo, 2006.

SAFFIOTI, Heleieth. A mulher na sociedade de classes: mito e realidade. Petrópolis: Vozes, 1979.

SOIHET, Rachel. "Mulheres pobres e violência no Brasil urbano". In: DEL PRIORE, Mary. História das mulheres no Brasil. São Paulo: Contexto/EDUNESP, 1997.

ROHDEN, Fabíola. A arte de enganar a natureza: contracepção, aborto e infanticídio no início do século XX. Rio de Janeiro: Fiocruz, 2003.

RIBEIRO, Gláucio Vasconcelos. Infanticídio: crime típico, figura autônoma, concurso de agentes. São Paulo: Pillares, 2004.

TRIBUNAL DE JUSTIÇA DO ESTADO DO RIO GRANDE DO SUL. Acórdão de apelação criminal n. 70035118967. Disponível em: http://www.jusbrasil.com.br/jurisprudencia/ busca?q=Infanticidio+\&s=jurisprudencia. Acesso em: 25/07/2012.

TRIBUNAL DE JUSTIÇA DO ESTADO DO RIO GRANDE DO SUL. Recurso em sentido estrito. Júri. Apelação Crime n 700351 18967. Disponível em: http://www.tjs.jus.br/busca/?tb=proc. Acesso em: 27/10/2017.

[Recebido em 22/10/2015, reapresentado em 14/07/2016

e aprovado 05/04/2017]

The Infanticide as an Expression of Violence and Denial of Maternal Love Myth Abstract: In this paper we discuss the crime of infanticide in Brazil. We try to understand the historical roots of motherhood and violence, relating them to the social class category, therefore, the data point to the fact that the women involved with this kind of crime belongs in overall the popular classes. From that perspective, we present results of a research about the crime of infanticide in Brazil conducted at the State University of Goiás in 2012, entitled "The infanticide in Brazilian society: a study of the social, historical and cultural dimensions".

Keywords: Infanticide; Maternity; Violence; Woman

Veralúcia Pinheiro (veraluciapinheiro27@gmail.com) é Doutora em Educação pela Unicamp, professora em cursos de Graduação e no Programa de Mestrado Interdisciplinar em Educação, Linguagem e Tecnologias - MIELT - Campus de Ciências Socioeconômicas e Humanas da Universidade Estadual de Goiás.

12 Revista Estudos Feministas, Florianópolis, 26(1): e41476 